\title{
The Data and Design of the LANCHART Study
}

Gregersen, Frans

Published in:

Acta Linguistica Hafniensia: International Journal of Linguistics

Publication date:

2009

Document version

Peer reviewed version

Citation for published version (APA):

Gregersen, F. (2009). The Data and Design of the LANCHART Study. Acta Linguistica Hafniensia: International Journal of Linguistics , 41, 3-29. 
This article was downloaded by: [Copenhagen University Library]

On: 01 April 2014, At: 04:28

Publisher: Routledge

Informa Ltd Registered in England and Wales Registered Number: 1072954 Registered

office: Mortimer House, 37-41 Mortimer Street, London W1T 3J H, UK

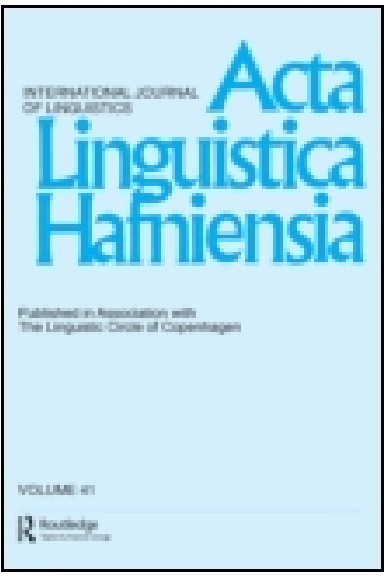

\title{
Acta Linguistica Hafniensia: International J ournal of Linguistics
}

Publication details, including instructions for authors and subscription information:

http:// www.tandfonline.com/loi/ salh20

\section{The data and design of the LANCHART study}

\author{
Frans Gregersen ${ }^{\text {a }}$ \\ a The LANCHART Centre, University of Copenhagen \\ Published online: 01 Dec 2009.
}

To cite this article: Frans Gregersen (2009) The data and design of the LANCHART study, Acta Linguistica Hafniensia: International J ournal of Linguistics, 41:1, 3-29, DOI: $10.1080 / 03740460903364003$

To link to this article: http:// dx.doi.org/ 10.1080/03740460903364003

\section{PLEASE SCROLL DOWN FOR ARTICLE}

Taylor \& Francis makes every effort to ensure the accuracy of all the information (the "Content") contained in the publications on our platform. However, Taylor \& Francis, our agents, and our licensors make no representations or warranties whatsoever as to the accuracy, completeness, or suitability for any purpose of the Content. Any opinions and views expressed in this publication are the opinions and views of the authors, and are not the views of or endorsed by Taylor \& Francis. The accuracy of the Content should not be relied upon and should be independently verified with primary sources of information. Taylor and Francis shall not be liable for any losses, actions, claims, proceedings, demands, costs, expenses, damages, and other liabilities whatsoever or howsoever caused arising directly or indirectly in connection with, in relation to or arising out of the use of the Content.

This article may be used for research, teaching, and private study purposes. Any substantial or systematic reproduction, redistribution, reselling, loan, sub-licensing, systematic supply, or distribution in any form to anyone is expressly forbidden. Terms \& Conditions of access and use can be found at http://www.tandfonline.com/page/termsand-conditions 


\title{
The data and design of the LANCHART study
}

\author{
Frans Gregersen*
}

The LANCHART Centre, University of Copenhagen

(Received 7 August 2008; final version received 14 September 2009)

\begin{abstract}
In this introduction to the volume of papers from the Danish laboratory, both the design of the LANCHART study of language change in real time and the data collected according to the design are described. Starting from a delimitation of the problem field, we progress to a detailed description of the original eight studies making up the starting point for the centre as well as the seven repetitions that were carried out during 2005-2007. Explanations of the choices as to the selection of geographical sites as well as to speaker variables of age and class are given, and problems with the choices are mentioned. In the concluding section, the other papers of the volume are briefly presented.
\end{abstract}

Keywords: language change in real time; Danish language varieties; design and data

\section{Introduction: The problem: Language variation and change}

Language variation and change have so often in the past been tied to each other that we may speak of a paradigmatic field consisting of LVC, hence the name of one of the leading sociolinguistic journals, Language Variation and Change. The original argument is best presented in the trailblazing monograph long paper by Weinreich, Labov and Herzog from 1968. Here the object of attack is the structuralist notion of a system où tout se tient (i.e. every element has its place, and the structure as such is defined both by the elements and their relations). If it is not possible to change any element without arriving at a totally different structure, then of course it follows that either we are talking of language at a very abstract level or we are talking of a sort of mean of the many different uses we meet with every day - the notion of the common core. For both views, variation is something to get rid of and anyway change cannot be observed.

The countermove was to start studying variation as a gateway to change. The massive variation in New York City English was precisely the subject of the dissertation by William Labov which may be said to have founded sociolinguistics (Labov 1966 (2006)). So much of what we now take for granted when we practice sociolinguistics was presented here for the first time. The distinction between studying change in apparent time and studying changes in real time was however introduced already in the famous paper on Martha's

\footnotetext{
*Email: fg@hum.ku.dk
} 
Vineyard (1963). Taking the study by Gauchat (1905) as his paradigmatic example, Labov notes that Hermann returned to Charmey and comments:

Yet Hermann (1929) also showed that real time depth is essential for an accurate view, since the fourth feature [in contrast to the first three, FG] had not changed since 1903, and was apparently subject to a number of conflicting influences. (Labov 1963 (1972), 23)

In 1964 this notion of real time is contrasted with apparent time in the paper on Hypercorrection:

We can now approach the question of linguistic change, particularly as it affects the phonological variables. In this discussion, the principal approach to change will be through internal evidence, in the distribution of linguistic behavior through the various age levels of the population. This distribution forms a dimension which we may call apparent time, as opposed to real time. (Labov 1964 (1972), 133)

By 1966 this had become a major theme, treated in detail in Chapter 9 of the dissertation. In the second edition from 2006, Labov with hindsight comments on this chapter as follows:

The first eight chapters of this book concern synchronic patterns of variation in the speech community, with the linguistic variable as the working tool of analysis. There have been hints about linguistic change in progress but it is not until this chapter that sociolinguistics takes on the study of change and variation as its central problem. (Labov 2006, 199)

It is this central problem of sociolinguistics we have focussed on in the LANCHART project.

\section{The LANCHART project, its aims}

There are two ways to study language change in real time. Either we may find the original informants of the first study (the S1, as we shall call it throughout) and subject them to the same or a similar study (the S2) at a later point in time to see whether they have changed. Or we may construct a sample of informants following the same criteria as those we used in the S1 and then study them for our S2. The first design is called a panel study while the second one is known as a trend study. The LANCHART project which was started in 2005 through a grant from the Danish National Research Foundation, primarily uses the panel design, but in one case (viz. Odder cf. below section 3.3) we have also used the trend design so that we are able later to control for the validity of results obtained by the two designs (Sundgren 2004).

The LANCHART project thus consists of a number of coordinated and comparable panel studies of language change in real time carried out at 6 different sites in Denmark. The purposes of the study are:

- to shed light on the general question of language change by looking both at the individual and the group in real time, cf. e.g. Gregersen, Maegaard and Pharao, this volume, Juel Jensen, this volume 
- to elucidate a number of methodological questions of how one can in general carry out comparable studies in real time or make data comparable which were not collected using the same techniques and/or methods in the S1 and the S2, cf. Gregersen, Beck Nielsen and Thøgersen, this volume

- to document linguistic variation at various levels in spoken Danish (both as a first and as a second language) at the two primary points in time represented in the study, i.e. 1986-90 to 2005-07, cf. Juel Jensen, this volume, Gregersen, Maegaard and Pharao, this volume, Møller and Normann Jørgensen, this volume

- to document what varieties of linguistic features (in traditional parlance, which languages) were used in the period under study and what changes in their use occurred, cf. Møller and Normann Jørgensen, this volume

- to document the linguistic changes which happened during the period 1986 to 2007 and their relationship with the variation, cf. Pedersen and Schøning 2006, 2007

- to investigate whether interaction may explain different sociolinguistic patterns of use, cf. e.g. Beck Nielsen, Fogtmann and Juel Jensen, this volume

- to uncover the social meaning of the documented linguistic variation in the various speech communities which make up the Danish society by performing various types of language attitudes studies, cf. Kristiansen, this volume

- to reveal any simple or complex relationship between the historical processes which have changed Danish society 1986-2007 and the linguistic changes in the same period

When we started the LANCHART centre in 2005 we were inspired by the variation and change approach to sociolinguistics and thus set out to study variation in both apparent and - predominantly - real time. In Denmark a number of relevant original studies had been carried out over a relatively short span of time and suggested themselves as candidates for repetition. The S1s were most of them from the late 80 s which gave us the chance to repeat the studies while most of the informants were still alive.

\subsection{The original studies which are part of the LANCHART study}

The studies are the following eight ones:

- The Vinderup language study (Kristensen 1977) ${ }^{1}: 119$ informants of mixed age audio recorded in 1973 (VINDERUP 1) and $248^{\text {th }}$ graders recorded in 1978 (VINDERUP 2) (Kristensen 1980) by Kjeld Kristensen.

\footnotetext{
${ }^{1}$ I would like to express our deep gratitude to Kjeld Kristensen for generously placing all his material from the early investigations at our disposal.
} 
- The Odder project (Jul Nielsen and Nyberg 1992f) ${ }^{2}, 71$ informants of mixed age audio recorded 1986-89 by dialectologists Bent Jul Nielsen and Magda Nyberg (OdDER).

- The Vissenbjerg study of language use and language attitudes (Pedersen 1994): 32 informants of mixed age taped in 1982-83. Of these 13 have already been interviewed again in 1998-99 (VISSENBJERG). 6 new informants were recorded in 1998-99. The study was the work of Inge Lise Pedersen.

- The Copenhagen project in Urban Sociolinguistics (BYSOC) (Gregersen and Pedersen 1991): a total of 87 informants, distributed among four age groups with a core group of 24 informants in the age group 25-40 years of age and a group of 20 young informants, all of them recorded by the same three field workers 1986-87. The project was directed by Frans Gregersen and Inge Lise Pedersen.

- The study of Modern Zealand levelled dialect in Næstved (ModsJÆL), (Jørgensen and Kristensen 1994); a core group of $2 \times 24$ plus 12, in sum 60 informants from three different high schools have been recorded at least twice and several of them three times 1986-89. A supplementary group of 22 informants were added, thus in total 82 informants participated in the original ModsJÆL study. The study was directed by Kjeld Kristensen and Jens Normann Jørgensen.

- The Næstved study of language attitudes and language use (NÆSTVED) (Kristiansen $1998^{3}$ ), a total of 130 persons, a group of 48 adults, a group of 41 adolescents and a group of 41 children (recorded twice), all of them recorded during the years 1986-1989 by Tore Kristiansen himself.

- The Køge longitudinal project (KøGE) (cf. for an introduction: Jørgensen 2003): A total of 105 grade school students from Dano-Turkish as well as Dano-Danish backgrounds were recorded; 12 of the Turko-Danish kids were recorded each year 1989-1997. The study was originally directed by Jens Normann Jørgensen, Anne Holmen and Jørgen Gimbel.

- Project DASVA on the language contacts and language attitudes of Danes and Swedes in the Øresund region (Gregersen and Svensson 2002, Gregersen and Kristiansen forthc.): A total of 16 Danish informants recorded by three field workers in 2001 (DASVA). (16 Swedish informants were also tape recorded as part of this project, but they are not included in the LANCHART project).

\footnotetext{
${ }^{2}$ I would like here to express our deep gratitude to Bent Jul Nielsen and Magda Nyberg for generously placing all their material from the early survey at our disposal.

${ }^{3}$ The LANCHART Danish website includes references to publications concerning the studies, including the Næstved study, which has been published extensively both in Danish and in English. Please look at the website (www.dgcss.dk, om dgcss, unders øgelsesområder) for further references not only to the NÆSTVED study but also the other LANCHART studies.
} 
These 8 studies form the base for our work. In the following we shall adopt the convention of referring to the original studies as the S1s while the LANCHART re-recordings are consistently called the $S 2 s$.

The geographical location of the various sites is shown in Figure 1:

\subsection{Generations and core groups}

\subsubsection{Generation 1}

The sheer magnitude of the original database (a total of 537 informants) forced us to concentrate on a core group. Two considerations guided us in this choice.

First, we had to look at the geographical coverage. We were interested in being able to test the predictions of various standardization models (Auer 2005, Kristiansen, this volume), and that would demand Jutland projects (cf. the map, fig.1 Jutland is the westernmost peninsula). We chose Odder as the Jutland project for the core group of generation 1, for a number of practical reasons outlined below, section 2.2.1. The two Jutland projects, Odder and Vinderup, differ in a number of respects, however, not least the position of the traditional

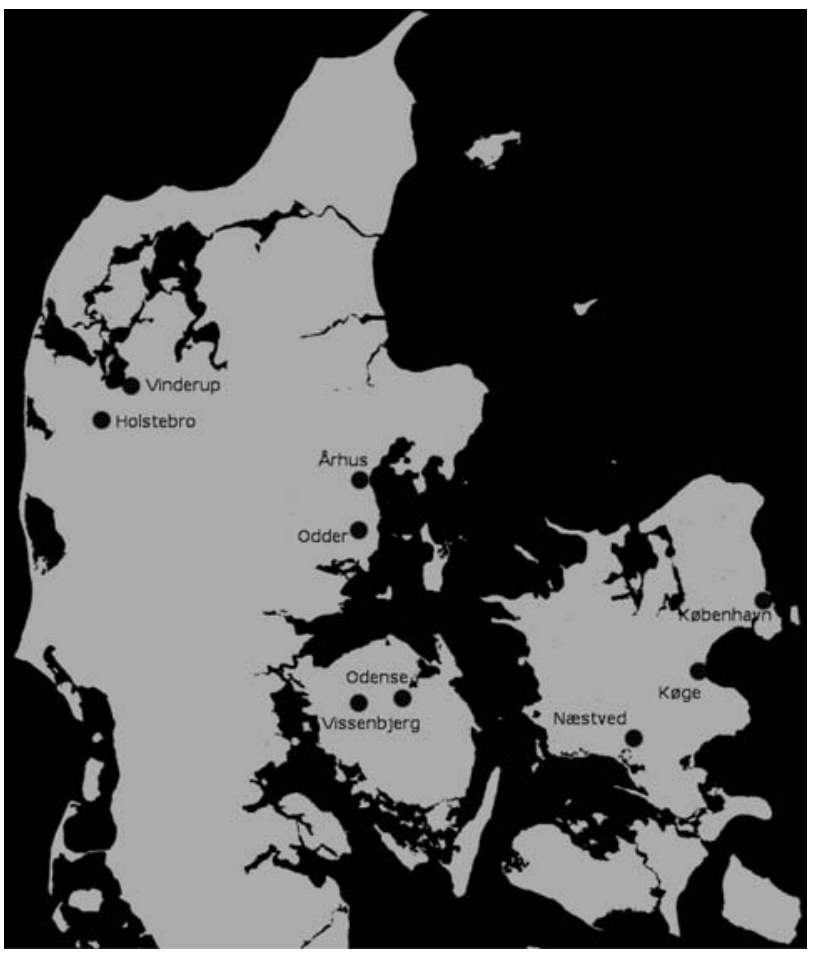

Figure 1. Map of Denmark showing the LANCHART sites. 
dialect in the community (Pedersen and Schøning 2006, 2007 point out that the traditional dialect is present in the Vinderup community whereas this is hardly the case in Odder), and the geography of the sites, Vinderup being decidedly more westwards than Odder. This is why it was important to include the Vinderup generation 2 informants, cf. below, section 2.2.2.

For the Zealand area we had Næstved, a city under the dominance of the capital, and Copenhagen, the capital itself, as our selected sites.

The second consideration was that of getting a robust representation of the same generation of speakers across sites. The Copenhagen project had focussed on the generation who at the time of S1 (1986-1988) were between 25 and 40 years of age and had aimed at a design with 5 informants in each cell, defined by social class (Working Class (WC) and Middle Class (MC) cf. below section 2.3) and gender (M(ale) and $\mathrm{F}($ emale $)$ ). We took that as our starting point and defined this generation as generation 1. It was possible to increase the number of informants in each of the four cells to six and to find enough informants in the Næstved S2, but, unfortunately, not in Odder, cf. below, to fill out a design such as the one depicted in Table 1:

Ideal designs rarely correspond to reality. The degree of correspondence may be seen in Table 2:

The core group of generation 1 informants thus consists of 24 informants from the capital of Copenhagen 19+5 informants from Næstved, a regional

Table 1. Ideal design for the core group of persons who in 1986-88 were between 25 and 40 years of age, i.e. born between 1942 and 1963 (generation 1).

\begin{tabular}{lllllll}
\hline & Næstved & \multicolumn{3}{l}{ Odder } & \multicolumn{3}{l}{ Bysoc } \\
\hline S1 & $6 \mathrm{MC} \mathrm{m}$ & $6 \mathrm{MC}$ & $6 \mathrm{MC} \mathrm{m}$ & $6 \mathrm{MC}$ & $6 \mathrm{MC} \mathrm{m}$ & $6 \mathrm{MC} \mathrm{f}$ \\
& $6 \mathrm{WC} \mathrm{m}$ & $6 \mathrm{WC} \mathrm{f}$ & $6 \mathrm{WC} \mathrm{m}$ & $6 \mathrm{WC}$ & $6 \mathrm{WC} \mathrm{m}$ & $6 \mathrm{WC} \mathrm{f}$ \\
S2 & $6 \mathrm{MCm}$ & $6 \mathrm{MC} \mathrm{f}$ & $6 \mathrm{MC} \mathrm{m}$ & $6 \mathrm{MC}$ & $6 \mathrm{MC} \mathrm{m}$ & $6 \mathrm{MC} \mathrm{f}$ \\
& $6 \mathrm{WC} \mathrm{m}$ & $6 \mathrm{WC} \mathrm{f}$ & $6 \mathrm{WC} \mathrm{m}$ & $6 \mathrm{WC} \mathrm{f}$ & $6 \mathrm{WC} \mathrm{m}$ & $6 \mathrm{WCf}$ \\
\hline
\end{tabular}

Table 2. The core group generation 1 informants from NÆSTVED, ODDER and Copenhagen BYSOC. Some of our informants in the NÆSTVED S2 did not participate in the S1. Hence the increase in S2 numbers. In the SUM row you can see first how many persons are found in both S1 and S2 recordings, and next how many recordings will have to be processed by the project.

\begin{tabular}{lllllll}
\hline & Næstved 1 & & Odder 1 & \multicolumn{3}{l}{ Bysoc 1 } \\
\hline S1 & $6 \mathrm{MC} \mathrm{m}$ & $6 \mathrm{MC} \mathrm{f}$ & $2 \mathrm{MC} \mathrm{m}$ & $2 \mathrm{MC} \mathrm{f}$ & $6 \mathrm{MC} \mathrm{m}$ & $6 \mathrm{MC} \mathrm{f}$ \\
& $3 \mathrm{WC} \mathrm{m}$ & $4 \mathrm{WC} \mathrm{f}$ & $4 \mathrm{WC} \mathrm{m}$ & $3 \mathrm{WC} \mathrm{f}$ & $6 \mathrm{WC} \mathrm{m}$ & $6 \mathrm{WC} \mathrm{f}$ \\
S2 & $6 \mathrm{MC} \mathrm{m}$ & $6 \mathrm{MC} \mathrm{f}$ & $2 \mathrm{MC} \mathrm{m}$ & $3 \mathrm{MC} \mathrm{f}$ & $6 \mathrm{MC} \mathrm{m}$ & $6 \mathrm{MC} \mathrm{f}$ \\
& $6 \mathrm{WC} \mathrm{m}$ & $6 \mathrm{WC} \mathrm{f}$ & $4 \mathrm{WC} \mathrm{m}$ & $3 \mathrm{WC} \mathrm{f}$ & $6 \mathrm{WC} \mathrm{m}$ & $6 \mathrm{WC} \mathrm{f}$ \\
SUM & $9 \times 2: 18$ & $10 \times 2: 20$ & $6 \times 2: 12$ & $5 \times 2: 10$ & $12 \times 2: 24$ & $12 \times 2: 24$ \\
\hline
\end{tabular}


centre south of Copenhagen on the island of Zealand, and finally $11+1$ informants from Odder in Jutland, the most levelled of the two Jutland sites ${ }^{4}$.

\subsubsection{Generation 2}

The pupils from VINDERUP 2 who were at the time of their first recording in 1978 between 14 and 15 years of age, correspond in birth dates to the generation who were recorded by the BYSOC project in Copenhagen when they were between 15 and 24 in 1986-87. Furthermore 12 ODDER informants fit into this as well, cf. Table 3 below.

As will be documented below, the project has the possibility of getting several additional informants for the generation 2, viz. from both ODDER and NÆSTVED: Tore Kristiansen in his S1 interviewed a group of adolescents, cf. section 3.5.1. These informants have already been re-recorded by the LANCHART project. The same is true for a number of Odder informants not represented in Table 3.

\subsubsection{Generation 3}

We have recorded generation 3 consisting of children who were in their 8th or 9th grade in school in Vinderup, Odder and Næstved. The recording of generation 3 in Copenhagen is planned for the fall of 2009.

The recordings in Odder and Vinderup consist of single interviews only while the recordings in Næstved include both single person interviews and group discussions in order for the data to be compatible both with the NÆSTVED and ModSJeL S1s. The data is condensed in Table 4 below.

\subsection{Social classes}

We have not carried out an independent study of the social stratification of the Danish society as a whole, nor of the various local communities, or for that matter Copenhagen. Rather, we have interpreted traditional sociological categories and attempted to adapt them as best we could to local conditions. The Copenhagen BYSOC project (Gregersen and Pedersen 1991) developed a classification based on three indicators, viz. education, power in the work place and the specific content of the working process 5 .

\footnotetext{
${ }^{4}$ It has been possible to find a number of Odder informants who have been interviewed twice and who more or less correspond to the original criteria as to class affiliation but the interviews have not been transcribed fully yet and in the following we will neglect them. ${ }^{5}$ Note that income is not taken into account. A more thorough discussion of the social categories used in the BYsoc S1 which was used as the model for the other S1 (re-)classifications as well, may be found in Gregersen, Albris and Pedersen 1991, 19ff. In the BYSOC S1 we used a further criterion of family background which was all the easier to apply in the BYsoc S1 as the traditional Nyboder neighbourhood in Copenhagen was a place which featured many families and close-knit networks. Thus a fair number of our BYSOC informants are related.
} 
Table 3. The core group generation 2 (born between 1964 and 1973) from VINDERUP, ODDER and Copenhagen, BYSOC. In the SUM row you will see first how many persons are recorded twice and then the resulting number of recordings to be processed by the project.

\begin{tabular}{lllllll}
\hline & Vinderup 2 & & Odder 2 & \multicolumn{3}{c}{ Bysoc 2 } \\
\hline S1 & $4 \mathrm{MC} \mathrm{m}$ & $6 \mathrm{MC} \mathrm{f}$ & $4 \mathrm{MC} \mathrm{m}$ & $3 \mathrm{MC} \mathrm{f}$ & $5 \mathrm{MC} \mathrm{m}$ & $5 \mathrm{MC} \mathrm{f}$ \\
& $3 \mathrm{WC} \mathrm{m}$ & $6 \mathrm{WC} \mathrm{f}$ & $2 \mathrm{WC} \mathrm{m}$ & $3 \mathrm{WC} \mathrm{f}$ & $4 \mathrm{WC} \mathrm{m}$ & $4 \mathrm{WC} \mathrm{f}$ \\
S2 & $4 \mathrm{MC} \mathrm{m}$ & $6 \mathrm{MC} \mathrm{f}$ & $4 \mathrm{MC} \mathrm{m}$ & $3 \mathrm{MC} \mathrm{f}$ & $5 \mathrm{MC} \mathrm{m}$ & $5 \mathrm{MC} \mathrm{f}$ \\
& $3 \mathrm{WC} \mathrm{m}$ & $6 \mathrm{WC} \mathrm{f}$ & $2 \mathrm{WC} \mathrm{m}$ & $3 \mathrm{WC}$ & $4 \mathrm{WC} \mathrm{m}$ & $4 \mathrm{WC} \mathrm{f}$ \\
SUM & $7 \times 2: 14$ & $12 \times 2: 24$ & $6 \times 2: 12$ & $6 \times 2: 12$ & $9 \times 2: 18$ & $9 \times 2: 18$ \\
\hline
\end{tabular}

Education: Those who have twelve years of school plus more than a four year long further education belong to the Middle Class (MC). This means that we mainly capture academics as members of this class but even teachers fall into this category. One might very well question whether formal education, and this is what 'education as an indicator' means, is central to modern sociological structure. As the general population gets better educated, the level of education which contributes to the cultural capital or distinction of the individual (Bourdieu 1979, 1991) must necessarily increase to make a difference. On the other hand, lack of further education than basic schooling might become more distinctive.

All informants who had only compulsory schooling belong in the Working Class (WC). Compulsory schooling means 9 or 10 years of school for informants relevant to the S2s, but for the older part of the population it is less: a fair number of them had only 7 years of compulsory schooling.

Power: We combined the indicator of education with the notion of 'power in the work place'. In the S1s we rarely asked direct questions about how many persons the informant was able to issue orders to. Thus, we had to apply a fair amount of guesswork based on our knowledge of how workplaces in Denmark are structured. In most cases they are fairly hierarchical and so the classification of the informants as to whether they had the authority to direct more than 10 people or worked with no superior (MC) or had subordinate jobs or less than 10 people to direct (WC) was in most cases manageable.

Content: Finally, we classified the informants into two groups: working with material goods (WC) and working with immaterial goods, i.e. language or symbols (MC).

Table 4. The generation 3 (born between 1989 and 1994) data set.

\begin{tabular}{lllllll}
\hline & Vinderup 3 & \multicolumn{3}{c}{ Odder 3 } & \multicolumn{3}{c}{ Næstved 3 } \\
\hline S1 & $4 \mathrm{MC} \mathrm{m}$ & $5 \mathrm{MC}$ & $4 \mathrm{MC} \mathrm{m}$ & $4 \mathrm{MC} \mathrm{f}$ & $9 \mathrm{MC} \mathrm{m}$ & $11 \mathrm{MC} \mathrm{f}$ \\
& $10 \mathrm{WC} \mathrm{m}$ & $11 \mathrm{WC} \mathrm{f}$ & $10 \mathrm{WC} \mathrm{m}$ & $15 \mathrm{WC} \mathrm{f}$ & $7 \mathrm{WC} \mathrm{m}$ & $5 \mathrm{WC} \mathrm{f}$ \\
SUM & 14 & 16 & 14 & 19 & 16 & 16 \\
\hline
\end{tabular}


In most cases in Copenhagen we had sufficient information to draw a conclusion but it should be mentioned that we have deliberately excluded a change of class affiliation although some few informants have obviously changed. The reason is that a real time panel study is mostly - but not exclusively a study of individuals. If the individuals change their class affiliation, this is a fact about them which must be taken into account in the analysis. We could not preclude it in the data collection process, nor preclude the informants from doing so in reality. In the generation 1 it is a witness to the stability of the communities studied that so few of the informants did in fact change.

Outside Copenhagen, and particularly in Vinderup, the class pattern is very different and some of the classifications gave us severe problems here. We have nevertheless decided upon using this very rough classification in order to give an impression of what is certainly a more complex reality.

\section{The studies}

\subsection{The Thelander-Gumperz inspiration and the Vinderup study}

Kjeld Kristensen carried out two rather different investigations of the spoken language varieties in Vinderup. We refer to the early studies as VINDERUP 1 (1973) and VINDERUP 2 (1978 and 2006) respectively.

VINDERUP 1 is the oldest of the studies in the LANCHART project. The conversations in VINDERUP 1 were very short and it would be hard to get enough data for a comparison with an S2. Accordingly, we have chosen to concentrate on repeating the interviews with informants from the VINDERUP 2, VINDERUP 1 functioning as a very convenient, detailed baseline for the speech community under study. Please remember that VINDERUP 1 thus exclusively refers to the original S1 since there is no LANCHART repetition of this particular S1, whereas VINDERUP 2 may refer to both the original S1 (1978) and the LANCHART S2 (2006).

The number 2 in VINDERUP 2 refers to the generation interviewed. The informants from the VINDERUP $2 \mathrm{~S} 1$ share birth-years with the ODDER generation 2 and the BYSOC generation 2 (although these informants were interviewed at various points in their lives, while the VINDERUP 2 informants all were pupils in the eighth grade at the time of the $\mathrm{S} 1$ ).

Below there is an account of the two original Vinderup-investigations, of LANCHART's re-recording the original informants from VINDERUP 2 and of the collection of a new data set called VINDERUP 3.

\subsubsection{The VINDERUP 1 S1}

The collection of data for VINDERUP 1 took place in 1973. The main aim of the investigation was to achieve a thorough and reliable description of the phonetic and morphological variation in this comparatively small West Jutlandic speech community with particular attention being paid to the use of the various so-called 
codes: traditional dialect, regiolect (levelled dialect), and the standard language. The material for the investigation consisted of interviews with 119 inhabitants from the Vinderup municipality. Interviews lasted between 6 and 10 minutes, so they were by LANCHART standards very short.

The result of the $\mathrm{S} 1$ was that it was only to a very small extent possible to shed light on the question of code-shift. There were only two informants who were able to produce codes that were different enough from each other for Kristensen to accept that they could have a social significance.

\subsubsection{The VINDERUP 2 S1}

The theoretical underpinning of the various studies undertaken by Kjeld Kristensen and later by Jens Normann Jørgensen dates back to John Gumperz' early study of Hemnesberget (with Blom). This study was a major inspiration for Mats Thelander and his group at the Uppsala University unit called FUMS. The essential feature of this tradition is that the situation is seen as the primary determinant of intra-individual variation. Kjeld Kristensen has published with Mats Thelander and was heavily influenced by his Burträsk studies (Thelander 1979, Kristensen 1980, 38ff). The result is a methodology which explicitly rejects Labovian sociolinguistic interviews (ibid.) in favour of attempts to elicit contrasting styles by placing informants in short, sometimes very short, formal interviews and afterwards recruiting them for (longer) group conversations where the field worker is not present. Obviously, the group conversation situation calls for ingenious solutions both to the technical problems of recording four persons at once and to the complication that the groups are not, and for obvious reasons of design cannot be, self-recruited and thus need a motive for communication. The solutions have varied but in the VINDERUP $2 \mathrm{~S} 1$ this was indeed a complicating factor, which led to various modifications during the early recordings (Kristensen 1980, 54).

The Vinderup 2 S1 collection of data took place in 1978. The aim was to carry out a dialect-sociological investigation of intra-individual variation in two different situations. The investigation was also designed to develop an experimental method that could be used for studies of bi-dialectism in the Danish dialect areas, particularly in the case of West Jutlandic school-pupils.

The material consisted of interviews lasting for about 7-8 minutes (the first situation, deliberately formal), as well as group recordings (the second situation, deliberately informal) lasting about 40 minutes and including 4 pupils each. 3 of the groups included pupils from the countryside while the remaining 3 included only pupils from the town of Vinderup itself (Kristensen 1980, 52f.). In total 24 pupils from the eighth grade participated.

With the methods developed there was not much success with eliciting bi-dialectism, probably because there was not sufficient distance of formality between the two situations. To take an obvious example: only one single pupil shifted code from 'jeg' to 'a' (the standard vs. the Jutland dialect form of the first 
person singular pronoun) between the two situations. At least at the time of the $\mathrm{S} 1$, this was a fairly reliable indicator of the two codes of traditional dialect and some form of regiolect.

\subsubsection{The VINDERUP 2 S2}

In LANCHART's replication of VINDERUP 2 the aim was to carry out new, deliberately informal, sociolinguistic interviews with all 24 informants. We have succeeded in locating and interviewing 19 informants. Note that in this particular case the $\mathrm{S} 2$ consciously is made less comparable to the $\mathrm{S} 1$ in order to facilitate comparisons with the studies from the other sites. Only at the Næstved site do we have sufficient data to be experimenting with two different set ups for the S2s.

\subsubsection{The VINDERUP 3 S1}

In order to make it possible to investigate change in apparent time in the Vinderup speech community we have extended the investigations by collecting interviews with 30 pupils from the ninth grade (cf. Table 4 above). The new data set will ensure that in the future it will be possible to investigate language change in real time by re-recording these 30 persons. The ninth grade is the final year of basic schooling in Denmark and thus the final year when informants of all backgrounds are in the same institutions.

\subsection{The MODSJEL study}

Jens Normann Jørgensen and Kjeld Kristensen's investigation of the spoken language in Næstved at the end of the 1980s is referred to here as the MoDSJÆL $\mathrm{S} 1^{6}$. It is contemporary with the Kristiansen NÆSTVED S1 but the two studies diverge as to aims and methods. The MoDSJeL S1 was an investigation of regional features in the spoken language of young people from Zealand and had two main aims:

- to describe the spoken regional language of Zealand, the island where Copenhagen, the capital of Denmark is situated, and

- to examine the proportions of local features of pronunciation to those closer to the (Copenhagen) standard language among young people in Zealand recorded in the same situations in three successive years.

The core group of informants consisted of 24 pupils from Næstved gymnasium and HF (Higher Preparatory Examination) and 24 persons enrolled in efg, i.e. pupils undergoing basic vocational training, at Næstved technical school. In addition, 12 day-pupils from Herlufsholm school (a private fee-paying boarding school) participated. In each of these groups the pupils were mixed so

\footnotetext{
${ }^{6}$ Derived from the name of the Jørgensen and Kristensen book length report (1994) on the study, entitled Moderne Sjacllandsk,
} 
that boys and girls, country folk and townspeople were evenly represented. The informants, all of whom were born in 1969-70 and thus belong to generation 2, were recorded three times at intervals of approximately one year, in 1986, 1987 and 1989, while they were attending the first, second and third years of their various educational courses.

In each year each individual pupil was recorded in two different conversational situations:

- a formal interview

- an informal group conversation

In the group conversations there were normally four participants, all of whom knew each others in advance. The composition of the groups with respect to the numbers of boys and girls and pupils from town and country varied. Note that this design is closely parallel to the design used for the VINDERUP 2 S1. This is no coincidence. Kjeld Kristensen was in charge of both of the projects (in the case of MoDSJÆL, though, he had Jens Normann Jørgensen as his co-director).

\subsubsection{The MODSJEL S1}

The main results of the MoDSJÆL S1 were that very little of the classical Zealand dialect had survived in 1986. In most respects, the young people in Næstved spoke the Copenhagen Standard variety of Danish. There were, however, a few exceptions; for example the young people had a more distinct Danish 'stød' (cf. Fischer-Jørgensen 1989, Basbøll 2005), and they had a 'stød' in small function words such as 'nu' (now), 'endnu' (yet) and pronouns like 'vi' (we).

Another result was that there was no difference between the spoken language of people from the country and from the town. There was a small difference between pupils at the gymnasium and those at the technical school, in that the latter spoke a slightly more markedly Zealand variety. The clearest distinction was between the boys and the girls. The girls spoke more conservatively than the boys. The boys had more raised [a]-sounds, they more often had a lowered [a] following the $/ \mathrm{r} /$ in e.g. words such as 'tretten' (thirteen), and they also demonstrated in other ways that their spoken language was more influenced by the Modern Copenhagen variety.

That the girls in Næstved spoke a less Copenhagen-influenced language than the boys is particularly interesting in the light of the results of the contemporary NÆSTVED project. In his analysis of the attitudes to language among young people in Næstved in 1986 Tore Kristiansen found that the girls had the most positive attitude to the modern Copenhagen standard language. A current theory about language change assumes that attitudes to language influence the user, i.e. that people, who, for example, regard the modern Copenhagen standard language as attractive without (at first) speaking it themselves, would be more likely to adopt features from it. Based on the results of the NÆSTVED S1 we would predict that the girls who in 1986 were more positive than the boys to the modern 
Copenhagen standard language would have adapted their own language so that now, 20 years later, they will speak a variety close to the modern Copenhagen language (cf. Kristiansen and Jørgensen 2005). This prediction goes both for the individual change on the part of the girls and for the distance to the boys, who were less attracted to the modern Copenhagen standard language. This assumption will to a certain extent be tested in the Gregersen, Pharao, Maegaard paper, this volume.

\subsubsection{The MODSJEL S2}

In contrast to the VINDERUP 2 S2, the aim of the ModSJeL S2 is to replicate as closely as possible the design of the original $\mathrm{S} 1$ with group conversations and short interviews in order to:

- compare the results of the ModsjÆL S1 and the ModsjÆL S2

- examine how the pronunciation of the informants varies according to situation, i.e. between the interview and the group conversation

- examine the link between the interactional variation of the informants in the group conversations (e.g. in the form of competition to get a chance to speak) and their social background

- examine the possible links between the original place of education of the informants and their present local, national or international orientation

- examine the possible links between the orientation of the informants and their linguistic development

In addition, it would be natural to examine how the informants' use of phonetic variables has changed and how these changes correlate with the general pattern of attitudes to language (variation) among the informants when they were young people in Næstved in 1986. We are particularly interested in finding out whether there is still a difference between the girls' (now women's) use of variants and that of the boys (now men), and whether the females - as predicted by the old investigations of attitudes to language - speak more Copenhagen-like today.

In the book length report on the original MoDSJÆL S1 (Jørgensen and Kristensen 1994) only the recordings from 1986 of the 48 schoolchildren in the core group and the 12 pupils from Herlufsholm were analysed. Recordings were made with an additional 22 pupils from Næstved gymnasium and the technical school but these were not analysed. The group of informants from which we could collect new data thus consisted of 82 individuals.

In the planning of the new interviews we have focused on the original informants from whom we have most material, viz. those who took part in both an interview and a group-conversation in all the three successive years, with a special emphasis on those who have already been analysed in the original report (Jørgensen and Kristensen 1994). We succeeded in locating and recruiting 47 of the original ModSJÆL informants. 24 of these were from the local Gymnasium, Næstved Gymnasium, while 15 were from the Technical School and 8 from the 
Næstved private gymnasium of Herlufsholm. A total of 16 informants have participated in all four rounds of recording. Only a fraction of the total number of recordings has been transcribed and by far most of these transcriptions are from the first year of recording.

\subsection{The dialectological tradition and the ODDER study}

Dialectologists Bent Jul Nielsen and Magda Nyberg carried out the ODDER S1. That they were dialectologists is evident both in the methodology and in the content of the interviews carried out. They set out to study what was left of the traditional dialects in an area where traditional dialect was threatened by the expanding city of Århus close by (cf. the map, fig.1). The Odder project thus represents one of many possible answers to the challenge of doing dialectology in a dialect levelled society.

\subsubsection{The ODDER S1}

Bent Jul Nielsen and Magda Nielsen collected data for the original survey of the spoken language in Odder in 1986-1989. The major aim of the original survey was:

- to give a full and balanced picture of the use of the varieties of Jutland traditional or levelled dialect for various purposes, how often and where they are used, with special emphasis on the relationship between the Jutland dialect and the modern standard, i.e. Copenhagen influenced, language variety.

The material from the survey consists of interviews with 71 inhabitants in the Odder municipality. The interviews lasted half an hour on average. Both fieldworkers took part in all the interviews. We see here a reflection of the dialectological tradition for field work focused on the expertise of the informant as to both linguistic and all other rural praxises (Gregersen, Møller and Pedersen 1994). In particular, the practice of being two interviewers creates a situation where the outsiders are numerically at an advantage. This is a difference which may be detected by an analysis of the discourse contexts in the resulting interviews, cf. the Gregersen, Beck Nielsen and Thøgersen paper, this volume.

\subsubsection{The ODDER $S 2$}

In the LANCHART repetition of the ODDER S1 it has been possible to locate and re-record 53 of the original 82 informants. From among these we selected a core group so as to fit the ideal of having 6 in each of the cells representing social background and gender. As noted above the ODDER S2 group of informants is, however, equally divided between generation 1 and 2, 12 in each generation.

In order to give a more rounded picture of the linguistic community in Odder today we have undertaken a number of supplementary interviews. Since a few of 
the original informants did not wish to take part in a new interview and others could not be located, it was necessary to supplement the original groups with 13 informants.

The field workers in Odder succeeded in recording both 7 more generation 2 informants and 27 informants who fill out the gap between generation 2 and generation 3, hence have been given the name of 'generation 25'. The Odder sample is thus the only one which allows us to perform both a trend study and a panel study. In addition, we may document language use in this particular community through an unbroken chain of generations.

\subsubsection{The ODDER 25 and 3 data sets}

We have thus established two new data sets corresponding to two different generations, Odder 25, which consists of 27 informants born between 1978-1981 and Odder 3 including 33 informants from the ninth grade and the gymnasium born 1987-1990 (cf. Table 4 above). The new groups will make it possible to detail linguistic variation and change in apparent time.

\subsection{The VISSENBJERG Study}

Vissenbjerg is the only site on Funen. Vissenbjerg is a small town quite close to Odense, the main city. Inge Lise Pedersen carried out the original analysis of variation in the spoken language of Vissenbjerg precisely because it was rather close to Odense a presumed norm centre competing with Copenhagen for the Funen area. In addition, she grew up there. The study is referred to as the VISSENBJERG S1.

\subsubsection{The VISSENBJERG S1}

The investigation formed part of a Scandinavian project on 'Urbanisation and language change in Scandinavia' under the direction of Bengt Nordberg, Uppsala (cf. Nordberg 1994).

The collection of data for the Vissenbjerg S1 took place in 1982 and 1983. The main aim was to find out how far the linguistic variation (particularly phonological and morphological variation) could be explained as a reflex of the mental urbanisation of the speakers, understood as an urban behavioural pattern that goes further than purely physical urbanisation. The informants' integration into a close-knit local network as well as their life mode (Højrup 1989, Pedersen 1994) was used as a measure of the degree of urbanisation of the informants.

The material for the linguistic investigation consisted of 32 interviews of approximately one hour's length, in most cases double interviews with the informants' spouses. The interviews also included an investigation of the language attitudes of the informants. The selection of informants took place in the 
way later described by Lesley Milroy as the friend of a friend-method. Inge Lise Pedersen is from Vissenbjerg herself. She could thus easily find a way into an extensive network and she was well known by several of the informants because of family links with the place.

\subsubsection{The VISSENBJERG S2}

13 of the ViSSENBJERG S1 informants in the youngest age-group, 7 women and 6 men, have been recorded again in 1998-1999 by Henriette Simonsen. In addition, a supplementary group of 6 informants were recorded. The new tape-recordings follow closely the original design of the project and Henriette Simonsen is also known in Vissenbjerg. In the LANCHART study we wish to employ the two rounds of recordings as a possibility for controlling the levelling of the dialect in a part of Funen which is close to Odense. At the same time the material can be used to monitor the spread of Copenhagen features to the Danish provinces. Finally, a language attitude analysis has been carried out at the Vissenbjerg school in the spring of 2007 so that we will have the possibility of comparing linguistic usage and attitudes to language, particularly the assessment of local Odense language and Copenhagen language.

\subsection{The Language attitudes paradigm and the NESTVED study}

The NÆSTVED study consists of a number of investigations of both language use and attitudes to language varieties. Informants were only individuals born, brought up and at the time resident in Næstved and its surroundings. The original investigation is referred to as the NÆSTVED S1, while the repetition is called the NÆSTVED S2. Tore Kristiansen carried out his NÆSTVED S1 at the same point in time as Kjeld Kristensen and Jens Normann Jørgensen directed their MoDSJÆL S1. Since the ModSJÆL S1 is predominantly about Næstveders as well, we are in the fortunate position of being able to connect the two studies both in apparent and real time. We have performed S2s for both of them, but the S2s could in this particular instance be tailor made so as to closely match the S1s which was not always possible at the other sites.

\subsubsection{The NESTVED S1}

The NeSTVED S1 consists of several studies all united by a common focus on attitudes to language. All of the studies were designed and carried out by Tore Kristiansen himself. Data was collected in the years 1986-1989 and again in 1998. The main aim of the studies was to identify and describe so-called 'linguistic norm ideals' (Kristiansen 1991) in the Næstved region in order to see whether a regional standard language could be predicted to have a future in Denmark (Kristiansen 1992).

The material for the sociolinguistic study of language use consisted of Labovian style sociolinguistic interviews with individuals from three different 
age-groups: children, adolescents and adults. In total, interviews were conducted with 130 informants. The 41 children were pupils in the third grade from three different municipal primary schools. Some of them were interviewed again when they were in the ninth grade. The group of adolescents consisted of 41 interviewees from eight different local youth educational institutions. They were interviewed once in 1986. Finally, the adult group consisted of 48 interviewees, evenly distributed as to gender, age and social background. They were all of them interviewed once in 1989.

Apart from this wide-ranging investigation of language use, Kristiansen carried out an extensive study of conscious and subconscious attitudes in the Næstved community to the varieties of spoken Danish. Kristiansen has to this end developed a specific methodology which is unique and has been refined in the LANCHART attitude studies which he synthesizes himself below, this volume.

Thus, the entire NÆSTVED study's special characteristic is its insistence on distinguishing between subconscious and conscious attitudes to linguistic varieties and their intricate relationship with patterns of language use. The subconscious attitudes are those expressed by the informants when they are not aware that the investigation is concerned with language matters, while the conscious attitudes are expressed when the informants are fully aware that they are being questioned about language. Kristiansen holds that positive attitudes to the local language are necessary on the subconscious level if one is to argue for the possible existence of a regional language norm ideal in Zealand.

In both the adult and the youth groups there was a clear conflict between the subconscious and the conscious attitudes to language. The adults were at the conscious level clearly less positive towards the regional language than towards Copenhagen standard Danish, while subconsciously, they reacted more favourably to the regional language (Kristiansen 1997). Among the young language users in Næstved, on the other hand, there was a distinct upgrading of the locally marked language in the conscious attitudes to language, while on the contrary, their subconscious attitudes showed a clearly disparaging attitude towards the local language in favour of the variety of Copenhagen.

Focusing on future users of language, i.e. the young people in the Næstved region, Kristiansen found no evidence for a future for a regional Zealandic language. Among the young people the Copenhagen language - and not the local language - formed the norm ideal that they aspired to achieve.

\subsubsection{The Nastved $S 2$}

In the LANCHART replication of the original Næstved S1 it has been possible to find and record 33 of the original 48 adult (i.e. generation 1) informants. From among these informants we have formed our core group of 24 informants. Note though that in particular the Working Class was not numerous enough to give us 6 informants in each cell (cf. Table 2 above). It turned out to be necessary to 
supplement the original group with 4 new adult informants (two married couples) in the WC cells.

Of the group of 41 informants who in 1986 were enrolled in youth educational institutions and thus belong to generation 2, we have located and interviewed 15 . Finally: Out of the 41 primary school pupils ('the children's group' in the original investigation) we have located and interviewed 21 informants. These informants all belong to generation 25 .

\subsubsection{The NESTVED 3 data set}

As with Odder and Vinderup, we have carried out interviews and group recordings with $329^{\text {th }}$ graders from the Næstved area in order to be able to study changes in apparent time and to furnish our heirs with fresh material for real time studies (cf. Table 4 above).

Thus, in Næstved we may contrast two different methods of data collection and still document the language use in the speech community throughout the generations.

\subsection{Urban sociolinguistics and the BYSOC project}

The Copenhagen Urban sociolinguistics project (the BYsoc S1) dealt with linguistic variation in Copenhagen. In contrast to the other studies the data were originally collected $1986-1988$ by three field-workers ${ }^{7}$ and not by the directors themselves. The project was directed by Frans Gregersen and Inge Lise Pedersen.

In the following brief introduction the term BYSOC S1 refers to the original study and BYSOC S2 to the new collection of material undertaken by LANCHART. Gregersen and Pedersen (1991) contains a full description of the BYSOC S1.

\subsubsection{The BYSOC S1}

The main aim of the BYSOC project was to examine how variation in the spoken language in a Copenhagen neighbourhood (Nyboder) corresponded to the classical speaker variables of sex, class and age, and with the degree of formality in the interaction.

The design of the project was inspired by William Labov's attention to speech-hypothesis (see e.g. Labov 1972, 1984). It was therefore the aim of the project to operationalize the concept of style and in particular to elicit intraindividual variation in Labovian style interviews (Labov 1984). The variation examined was that of pronunciation, syntax and narratives. Copenhagen became operationalized as the inner city - specifically the neighbourhood of Nyboder.

\footnotetext{
${ }^{7}$ Henrik Holmberg, Erik Møller and Jon Albris. A few of the interviews were recorded by Jane Jensen.
} 
Being easily delimited and having a distinctive and well-known history, the old naval quarter of Nyboder was the ideal quarter for a neighbourhood study dressed up as a study of Copenhagen speech. The primary informants have thus all spent their childhood and adolescence in Nyboder. For this reason the project is sometimes referred to as the Nyboder study.

The core data for the project consisted of sociolinguistic interviews with a total of 87 informants. These 87 informants were classified according to gender, social class and age group. The age groups were 15-24 years (age group I), 25-40 years (IIa), 41-59 years (IIb) and 60+years (III). These age groups formed the basis for the LANCHART core group generations. They may be defended as follows: The category 'Age group I' contains informants who have not yet found their station in life. They will most often be pupils or students of various sorts or people temporarily out of jobs and/or looking for a new one. This is in contrast to the age group IIa which includes informants who have finished education or are close to having done so, sometimes have got families or are planning to do so, and finally most of those who belong here are in jobs, although not necessarily their final jobs. Individuals belonging in 'Age group IIb', in contrast, most often are in their final jobs or at least at the final work place, and they are still not close to retiring (which in the navy happens earlier than elsewhere in the Danish society, please remember that the inhabitants of Nyboder were affiliated with the Danish navy). The age group III contains informants who have retired from the navy and their spouses.

What was at the time a sensible age group delimitation has lost some of its attraction since then, due to changes in society which make the workforce much less steady and conservative than it was in the 1980s. On the other hand, the advantages of using one and only one definition of the relevant generations superseded any qualms we might have in this respect. Anyway these qualms mostly have to do with the delimitation of age group III which is not relevant to the S2s of the LANCHART project.

Most of the recordings were interviews. For some informants, though, the interviews were supplemented with group-conversations, and in the case of a few informants there are recordings from radio interviews, job situations etc. In the original BYSOC report (Gregersen and Pedersen 1991) only the regular interviews were analysed.

A BySOC interview will typically last from one to two hours and is characterised by beginning with both the fieldworker and the informant being strangers to each other, while in the course of the interview some familiarity and intimacy is achieved. Compare the attention to speech-hypothesis, where the informant (and perhaps also the interviewer) changes from variants with high prestige to the vernacular as the degree of intimacy changes.

The project thus needed to operationalize formal and relaxed conversational style and developed a style analysis that could point out passages in the conversations on the basis of the following overall guidelines: 
Formal style

1. The interviewer controls the conversation

2. The topics in the conversation are not emotionally charged

3. The speed of the conversation can be described as standard

\section{Informal style}

1. No one individual controls the conversation

2. The topics are emotionally charged and are treated in an emotional manner

3. The informant deviates from his standard tempo

In the case of most of the informants it was possible to point to passages of both style types, and these passages formed the basis for further research. The style analysis is described in detail in Albris (1991).

Some of the results from the BYSOC S1 concerned phonetic variation. The statistical work on the phonetic variables revealed that gender, social class, age and style all played a role for the informants' use of variants. The results, together with a thorough examination of the statistical methods used, may be found in Holmberg (1991). The same recordings were also analysed with a focus on narratives (Møller 1991a and 1993) and from a functionally grammatical perspective (Nedergård Thompsen 1991).

\subsubsection{The BYSOC S2}

In the LANCHART replication of BYSOC $\mathrm{S} 1$ we have chosen to focus on two of the age groups mentioned above, viz. age group IIa and age group I. In the LANCHART project these - somewhat awkwardly - correspond to the generations 1 and 2 respectively. We have collected sociolinguistic interviews in Copenhagen with the original Nyboder informants following a template that is very close to the original one. This means that we quite often get the same stories and reminiscences at an interval of twenty years. Such data are particularly well suited for studies of individual linguistic change in real time.

The style analysis mentioned above suggested that 'degree of formality' was an important influence on the language use of the informants. This forced us to take intra-individual variation into account in the treatment also of our new data. The development of the so-called Discourse Context Analysis stems directly from this attempt to come to grips with intra-individual variation (cf. Gregersen, Beck Nielsen and Thøgersen, this volume).

Of the original informants in the BYSOC S1 generation 1 we succeeded in getting 24 re-recorded in the S2 so that each cell in the matrix contains exactly six informants. Of the BYSOC S2 generation 2 informants we have re-recorded 18. Their distribution may be seen in Table 3 above (section 2.1). 


\subsubsection{A BYSOC 3 data set?}

We plan to establish a data set which is comparable as to generation with the Vinderup 3, Odder 3 and NÆSTVED 3 data sets. This will be based upon the same ideas of sampling the generation via the schools, but in Copenhagen it is necessary to include the factor of ethnicity in the design so that we plan to interview 64 pupils in the eighth or ninth grades.

\subsection{The DASVA project}

The DASVA project had its origins in a joint effort on the part of a Swedish group directed by Jan Svensson and based at the University of Lund, and a Danish group at the University of Copenhagen directed by Frans Gregersen in cooperation with Tore Kristiansen, Jens Normann Jørgensen and Inge Lise Pedersen, to investigate the effects of the bridge which from the year 2000 connects the Swedish and the Danish side of the Øresund region (Gregersen 2003).

\subsubsection{The DASVA S1}

The original design of the study was from the start based on the ideas behind the acronym: Danish and Swedish in Accommodation ${ }^{8}$, i.e. that it would be interesting to see what factors influenced the choice of language varieties when Danes met Swedes. For this reason we searched for and found two types of work places at both sides of the Øresund, one with hardly any, or at best accidental, professional contact with persons talking Swedish (Danish), and one with intensive and regular contacts between Danish speaking and Swedish speaking persons. We found two low contact post offices and opted for the SAS as the work place with regular linguistic contacts.

We further hypothesized that an important factor determining degree of accommodation would be attitudes to the bridge and to the integration of Swedish and Danish in the region, and thus we started by carrying out a large scale questionnaire survey of the attitudes among the work force at the three sites. We had a poor ratio of returns but enough people answered at all three places for us to be able to select 16 Danish and 12 Swedish informants so that we would have two informants in each of the cells determined by gender (male/female), attitude (positive/negative) and high contact/low contact. The Danish informants were interviewed by Danish field workers and the Swedish subjects by Swedish field workers, both groups being subjected to a specially developed test of their understanding of Danish and Swedish respectively. Finally, they were recruited to participate in group conversations with their Swedish (or, for the Swedes, Danish) counterparts. The group conversations followed the line taken in the ModsJÆL and Vinderup studies documented above, in that we had planned

\footnotetext{
${ }^{8}$ Thus the English name ought to have been DASWA.
} 
activities for the informants to perform. However, two interviewers, one Swede and one Dane, were present.

A very important part of the project was to investigate language attitudes to Danish and Swedish at both sides of the border. In this investigation we developed a test which featured various degrees of modified SwedoDanish and DanoSwedish. Tore Kristiansen has reported on this study in Kristiansen 2004, 2005, 2005a.

Since we otherwise do not have very many data from the period just before the start of the centre, the LANCHART project will only use the 16 Danish DASVA interviews from 2001 as control material for the analysis of the BYSOC S2, in particular the generation 2 and 3 data sets. We may recur to this data set if we have doubts as to when a particular variable started to decline or when we want to date the arrival of new variables such as those discussed by Maegaard 2007.

\subsection{The KøGE project}

The KøGE project diverges in its design (but not in methodology) from the other LANCHART studies in that it is a longitudinal study and in that it focuses on Turkish-Danish speakers, i.e. children going to school in Køge who are born of Turkish speaking parents. Furthermore, the KøGE project has a parallel project in Eskişehir, Turkey which makes it possible to compare the acquisition and use of Turkish in Denmark with the acquisition and use of Turkish in Turkey. In addition, this design makes it possible to control for developments which are general in the sense that they are felt in Turkey as well as in Køge, in particular the tendency to mix features from various languages.

Through the years the fixed concept of 'a language' and the concomitant notions of 'language mixing' and 'code switching' have been felt to be more and more unhelpful in explaining what seems to go on in the recordings from the KøGE project. Consequently, Jens Normann Jørgensen has started a general attack on the theoretical concept of 'a language' and has suggested using the notion 'languaging' and 'languagers' to replace 'language use' and 'speaker'.

The KøGE project is arguably the only one of the LANCHART studies which has already been internationally published and received, cf. Jørgensen 2003 for an overview.

\subsubsection{The KøGE S1}

The collection of data started with a pilot project in 1987-89, but most of the data were collected between 1989 and 1998. The material was originally collected at two schools in Køge, but the researchers soon concentrated on following closely one group of students beginning school in 1989-90. Throughout this group's nine years of school varying data sets were collected with and around these kid informants, ranging from questionnaires to the teachers and questionnaires to the parents to regular recordings of single person interviews and group conversations while performing various activities (cf. the methodology developed in the 
Vinderup 2 and the Modsjel S1s). The groups varied as to their composition, boys only, girls only, mixed, Turko-Danish speakers only or mixed, and so on and so forth. This design means that it is possible to study the languaging of the individual languagers in the 12 person core group in various situations every year. Profiles of development may thus be drawn for both the individuals and the group of Turko-Danish speakers.

The aim of the project is, thus, to follow and describe the Turkish-Danish children's bilingual development. There are several aspects: a pedagogical aspect, a second language acquisition aspect and a bilingualism aspect. As mentioned above, the project has already given rise to a large number of publications and has for many years been the flagship within the burgeoning research-field of Danish as a second language?

\subsubsection{The KøGE $S 2$}

The establishment of the LANCHART centre meant that it became feasible to conduct a follow-up study to the original KøGE S1. The follow-up had three parts: Firstly, we located and re-recorded the original informants from the core group in single interviews and group conversations. The core group of the S1 belongs to LANCHART generation 3.

Janus Spindler Møller and Jens Normann Jørgensen succeeded in getting hold of 11 of the core group from the $S 1^{10}$. Secondly, Møller recruited the assistance of the core group members to perform a number of self-recordings in naturally occurring everyday situations with friends whom they would normally interact with. This method is comparatively new and has opened up possibilities of comparison which the original study did not have. In the paper by Janus Spindler Møller and Jens Normann Jørgensen in this volume, some of these possibilities are explored. The third feature was the recording of a new generation of eighth graders following the same recipe that was used in the original KøGE S1. This makes a detailed comparison in both apparent and real time possible and opens the door for future studies of this group as they reach the age when the original core group were re-recorded.

\section{Conclusion and a brief introduction to the papers below}

We have given a brief overview of the LANCHART project involving $8 \mathrm{~S} 1 \mathrm{~s}$ and thus correspondingly 8 possible S2s. The DASVA project is, however, not scheduled to be repeated for the time being and the VISSENBJERG S1 had already been repeated before the establishment of the LANCHART centre. This meant that 'only' six projects had to be repeated. We have also given an overview of the

\footnotetext{
${ }^{9}$ On http://dansk2.nordisk.ku.dk/upload/application/pdf/f51d6748/køgebibliografi07. pdf/ you will find a complete list of the relevant literature and a presentation of several of the contributors.

${ }^{10}$ Mediha Can conducted the interviews in Turkish whereas Janus Spindler Møller himself with the aid of two student assistants conducted the interviews in Danish.
} 
multi-faceted corpus this led to. We have specifically stressed the new possibilities for research in language variation in both apparent and real time and using both a trend design and - preponderantly - a panel design.

By way of concluding this paper, I shall briefly point to what aspects of this vast array of possibilities are treated in the papers below.

In the first paper, Gregersen, Beck Nielsen and Thøgersen give a description of the reason for developing a Discourse Context apparatus, i.e. to make the files from the many diverse projects comparable in various dimensions. The Discourse Context Analysis (DCA) is detailed and applied to the subset of files used in most of the papers, i.e. the generation 1 files from NæSTVED, OdDER and Copenhagen (BYSOC).

The paper by Gregersen, Maegaard and Pharao is concerned with the phonetic variable of short (a), in particular the segmental quality of the short [æ] used before alveolars and nil. The data sets used are those of the generation 1 in the Nestved S1 and S2s and the Bysoc S1 and S2s. The phonetic analysis builds on a DCA so that the passages which are analysed are selected from the same type of Discourse Context. Secondly, an auditory analysis has been performed giving each occurrence of the phonetic variant in question a specific value so that the full pattern of variants for each individual informant may be shown. Two types of analyses are performed and discussed in the paper, one concentrating on the individual, aiming at disclosing changes at the individual level in real time, and one looking at the group results to ascertain any difference of development between the two communities under study.

Torben Juel Jensen's paper deals with the use of the two possible generic pronouns of Danish 'du' (you $2^{\text {nd }}$ person pronoun) and 'man' (one specialized generic pronoun, $3^{\text {rd }}$ person). Juel Jensen's analysis is the only one which so far has used all the available data sets and has operated in both apparent time and real time.

The Juel Jensen analysis of the variation of generic pronouns in real time is the basis for the fourth paper, by Søren Beck Nielsen, Christina Fogtmann Fosgerau and Torben Juel Jensen, which boldly attempts to integrate such recognizably diverse disciplines as variationist quantitative sociolinguistics and, predominantly qualitative ${ }^{11}$, Systemic Functional Linguistics (SFL) and, distinctly qualitative, Conversation Analysis (CA) in an analysis of the contexts where one or the other of these two possible - and semantically almost equivalent - generic pronouns are used.

In the fifth paper, by Janus Spindler Møller and Jens Normann Jørgensen, the perspective is further broadened by including in the real time perspective of this volume the use of different codes by the Køge core group informants who were recorded during their school life and 9 years later in various contexts. The

\footnotetext{
${ }^{11}$ We are, of course, aware of the quantitative work done by Ruqaiya Hasan using SFL for precisely variationist sociolinguistic purposes (Hasan 2008) but the overwhelming bulk of the SFL work may not be characterized as quantitative, nor necessarily sociolinguistic.
} 
theoretical introduction to the paper sets out the conception of language guiding the research in Danish as a second language on 'language' and outlines a new approach to linguistic variation involving codes, introducing the term of polylingualism to capture essential aspects of the post modern linguistic condition.

In the final paper Tore Kristiansen gives an integrated account of the results of the many attitude studies which he has been directing through the years including the LANCHART studies of five of the six LANCHART sites.

\section{Notes on contributor}

Frans Gregersen is Professor of Danish, dr. phil., and Centre Director, for The Danish National Research Foundation LANCHART Centre at the University of Copenhagen, Institute of Scandinavian Studies and Linguistics

\section{References}

Albris, Jon. 1991. "Style analysis". In Gregersen, Frans and Inge Lise Pedersen (eds.): The Copenhagen Study in Urban Sociolinguistics, Part one (Institut for dansk Dialektforsknings publikationer, Serie A nr. 30). København: C. A. Reitzel, 45-106.

Auer, Peter. 2005. "Europe's sociolinguistic unity, or: A typology of European dialect/standard constellations". In Nicole Delbecque, Johan van der Auwera and Dirk Geeraerts (eds.): Perspectives on Variation. Sociolinguistic, Historical, Comparative (Trends in Linguistics, Studies and Monographs 163). Berlin/New York: Mouton de Gruyter, 7-42.

Basbøll, Hans. 2005. The Phonology of Danish. Oxford: Oxford University Press.

Bourdieu, Pierre. 1979. Distinction, a social critique of the judgement of taste. London: Routledge.

Bourdieu, Pierre. 1991. Language and Symbolic Power. Cambridge: Polity Press.

Fischer-Jørgensen, Eli. 1989. A Phonetic Study of the Stød in Standard Danish. University of Turku, Phonetics, February 1989 (photo-reprint from the original in ARIPUC 21, 1987:56-265).

Gregersen, Frans. 2003. "Factors influencing the linguistic development in the Øresund region". International Journal of the Sociology of Language 159. Tore Kristiansen and Jens Normann Jørgensen (eds.): The Sociolinguistics of Danish, 139-152.

Gregersen, Frans. 2007a. "The LANCHART Corpus of spoken Danish. Report from a corpus in progress". In Juhani Toivanen and Peter Juel Henrichsen (eds.): Current Trends in Research on Spoken Language in the Nordic Countries, volume II. Oulu: Oulu University Press, 130-143.

Gregersen, Frans, Jon Albris and Inge Lise Pedersen. 1991. "Data and Design of the Copenhagen Study". In Gregersen, Frans and Inge Lise Pedersen (eds.). 1991. The Copenhagen Study in Urban Sociolinguistics. Parts one and two. (Institut for dansk Dialektforsknings publikationer, Serie A nr.30). København: C. A. Reitzel, 5-43.

Gregersen, Frans and Inge Lise Pedersen (eds.). 1991. The Copenhagen Study in Urban Sociolinguistics. Parts one and two. (Institut for dansk Dialektforsknings publikationer, Serie A nr.30). København: C. A. Reitzel.

Gregersen, Frans, Erik Møller and Inge Lise Pedersen. 1994. "Field work traditions". Acta Linguistica Hafniensia 27/1: Jens Elmegård Rasmussen (ed.): Linguistic Studies in Honour of Jørgen Rischel. Copenhagen: C. A. Reitzel, 161-188.

Gregersen, Frans and Jan Svensson. 2002. "Bron och språket - en projektredogörelse". In Harald Gustavsson (red.): På jakt efter Öresundsregionen. Tankar och slutsatser från ett mångvetenskapligt forskningsprogram. Lund: Öreundsuniversitetet, 124-141. 
Gregersen, Frans and Tore Kristiansen. Fthc. DASVA rapport.

Hasan, Ruqaiya. 2009. Semantic Variation: Meaning in Society and in Sociolinguistics. (The Collected Works of Ruqaiya Hasan, Vol 2, edited by Jonathan J. Webster). London: Equinox.

Holmberg, Henrik. 1991. "The sociophonetics of some vowel variables in Copenhagen Speech". In Frans Gregersen and Inge Lise Pedersen (eds.): The Copenhagen Study in Urban Sociolinguistics. Part one. (Institut for dansk Dialektforsknings publikationer, Serie A nr.30). København: C. A. Reitzel, 107-239.

Højrup, Thomas. 1989. Det glemte folk. Livsformer og centraldirigering. Hørsholm: Institut for Europæisk Folkelivsforskning og Statens Byggeforskningsinstitut.

Jul Nielsen, Bentog og Magda Nyberg. 1992. "Talesprogsvariation i Odder kommune. I. Lokalsprog og rigsmål i sociolingvistisk belysning”. Danske Folkemål 34. København: C. A. Reitzels Forlag, 45-202.

Jul Nielsen, Bent og Magda Nyberg. 1993. "Talesprogsvariation i Odder kommune. II. Yngre og ældre rigsmålsformer i sociolingvistisk belysning”. Danske Folkemål 35. København: C. A. Reitzels Forlag, 249-348.

Jørgensen, J. Normann. 2003. "Bilingualism in the Køge Project". International Journal of Bilingualism vol. 7:4, 333-352.

Jørgensen, J. Normann and Kjeld Kristensen. 1994. Moderne Sjaellandsk. En unders $\emptyset$ gelse af unge sjallanderes talesprog. (Institut for Dansk Dialektforsknings publikationer, Serie A, nr. 32). København: C. A. Reitzel.

Kristensen, Kjeld. 1977. "Variationen i vestjysk stationsby-mål. En kvantitativ sociolingvistisk dialektundersøgelse i Vinderup, Ringkøbing Amt”. Dialektstudier 4/2. København: Akademisk forlag, 29-109.

Kristensen, Kjeld. 1980. "Situationsafhængig sprogbrug hos vestjyske skoleelever". Danske folkemål 22/2. København: Akademisk forlag, 29-124.

Kristiansen, Tore. 1991. Sproglige normidealer på Næstvedegnen. Ph.D. dissertation. Copenhagen: University of Copenhagen.

Kristiansen, Tore. 1992. "Har regionalsprog en fremtid i Danmark?" Danske folkemål 34, 203-247.

Kristiansen, Tore. 1997. "Language Attitudes in a Danish Cinema". In Nikolas Coupland and Adam Jaworski (eds.): Sociolinguistics. A reader and coursebook. London: Macmillan, 291-305.

Kristiansen, Tore. 1998. "The role of standard ideology in the disappearance of the traditional Danish dialects". Folia Linguistica XXXII(1-2): 115-129.

Kristiansen, Tore. 2004. “Sprogholdninger over Øresund”. Danske Talesprog 5: 161-185.

Kristiansen, Tore. 2005. "Nabosprog i Øresundsregionen. Et studie af reaktioner på sproglig tilpasning”. In Jens Cramer, Mette Kunøe og Ole Togeby. Teorien om alt. Århus: Wessel og Huitfeldt, 173-185.

Kristiansen, Tore. 2005a. "Holdninger til sproglig konvergens over Øresund". In Petter Dyndahl og Lars Anders Kulbrandstad (red.): High fidelity eller rein jalla? Purisme som problem i kultur, språk og estetikk. Vallset: Oplandske Bokforlag, 53-65.

Kristiansen, Tore and Jens Normann Jørgensen. 2005. "Subjective factors in dialect convergence and divergence". In Peter Auer, Frans Hinskens and Paul Kerswill (eds.): Dialect Change. Convergence and Divergence in European languages. Cambridge: Cambridge University Press, 287-302.

Labov, William. 1963. "The social motivation of a sound change". In William Labov: Sociolinguistic Patterns. Philadelphia: University of Pennsylvania Press, 1972, 1-42.

Labov, William. 1964. "Hypercorrection by the Lower Middle Class as a Factor in Linguistic Change". In William Labov: Sociolinguistic Patterns. Philadelphia: University of Pennsylvania Press, 1972, 122-142. 
Labov, William. 1966. The social stratification of English in New York City. Washington D.C.: Center for applied Linguistics.

Labov, William. 1972. Sociolinguistic Patterns. Philadelphia: University of Pennsylvania Press.

Labov, William. 1984. "Field Methods of the Project on Linguistic Change and Variation". In John Baugh and Joel Sherzer (eds.) Language in Use. Englewood Cliffs: PrenticeHall: $28-53$.

Labov, William. 2006. The social stratification of English in New York City. Second edition. Cambridge: Cambridge University Press.

Maegaard, Marie. 2007. "Udtalevariation og -forandring i københavnsk - en etnografisk undersøgelse af sprogbrug, sociale kategorier og social praksis blandt unge på en københavnsk folkeskole". Danske talesprog 8. København: C. A. Reitzel and Nordisk Forskningsinstitut, Afdeling for Dialektforskning.

Møller, Erik. 1991. "Narratives in the sociolinguistic interview". In Frans Gregersen and Inge Lise Pedersen (eds.): The Copenhagen Study in Urban Sociolinguistics. Part two. (Institut for dansk Dialektforsknings publikationer, Serie A nr.30). København: C. A. Reitzel, 241-335.

Møller, Erik. 1993. Mundtlig fortælling. København: C. A. Reitzel.

Nedergård Thomsen, Ole. 1991. "Grammar in Danish conversational discourse". In Frans Gregersen and Inge Lise Pedersen (eds.): The Copenhagen Study in Urban Sociolinguistics. Part two. (Institut for dansk Dialektforsknings publikationer, Serie A nr.30). København: C. A. Reitzel, 337-446.

Nordberg, Bengt (ed.). 1994. The Sociolinguistics of urbanization. The Case of the Nordic Countries. Berlin/New York: de Gruyter.

Pedersen, Inge Lise. 1994. "Linguistic Variation and Composite Life Modes". In Bengt Nordberg (ed.): The Sociolinguistics of urbanization. The Case of the Nordic Countries. Berlin/New York: de Gruyter, 87-115.

Pedersen, Inge Lise and Signe Schøning. 2006. "What happens at the end of the dialectstandard continuum?" Paper given at the ICLaVE 4, Cyprus.

Pedersen, Inge Lise and Signe Schøning. 2007. "Vinderup in real time - a showcase of dialect levelling?" Paper given at the ICHL in Montreal, accepted for publication in the proceedings.

Pedersen, Karen Margrethe. 1986. Mødet mellem sprogene $i$ den dansk-tyske granseregion. En-, to- og flersprogede børn i Sønderjylland. Aabenraa: Institut for grænseregionsforskning.

Pedersen, Karen Margrethe. 2003. "Border-region Danish". International Journal of the Sociology of Language 159. Tore Kristiansen and Jens Normann Jørgensen (eds.): The Sociolinguistics of Danish, 127-138.

Sundgren, Eva. 2004. Språklig variation och förändring: exemplet Eskilstuna. Lund: Studentlitteratur.

Weinreich, Uriel, William Labov and Marvin Herzog. 1968. "Empirical foundations for a theory of language change". In Winfred Lehmann and Yakov Malkiel (eds.): Directions for Historical Linguistics. Austin: University of Texas Press, 97-195. 